\title{
UJI EFEK ANALGESIK EKSTRAK ETANOL DAUN KEJI BELING (Strobilanthes crispus L) PADA TIKUS PUTIH GALUR WISTAR (Rattus norvegicus)
}

\author{
Ariesthya Dwi Cahyani Oliii ${ }^{1}$, Widdhi Bodhi ${ }^{1)}$, Hosea Jaya Edy ${ }^{1}$ \\ 1) Program Studi Farmasi FMIPA UNSRAT Manado, 95115
}

\begin{abstract}
Pain is an unpleasant sensory and emotional experience due to tissue damage both actual and potential. Analgesics are a drug used to relieve pain without losing consciousness. Keji beling leaves (Strobilanthes crispus L) contain glycosidic ester compounds from caffeic acid, which have analgesic effects. This study aims to determine whether there is an analgesic effect on the ethanol extract of keji beling leaves with different doses, namely dose $0.0023 \mathrm{~g} /$ $200 \mathrm{gBW}, 0.0047 \mathrm{~g} / 200 \mathrm{gBW}$, and $0.0094 \mathrm{~g} / 200 \mathrm{gBW}$ in test animals of wistar strain male rats. This study uses a laboratory experimental research design using wistar strain male white rat as a test animal. The analgesic effect test was carried out by the heat stimulation method using a $53{ }^{\circ} \mathrm{C}$ water bath. The rat response was observed in the form of movements of licking the hind legs or jumping from before giving test material and after giving test material at 30, 60, 90 and 120 minutes, respectively. From the results of statistical data analysis with One Way Anova and LSD showed that the extracts keji beling leaves has an analgesic effect. Where among those three doses the best dose was $0.0023 \mathrm{~g} / 200 \mathrm{gBW}$.
\end{abstract}

Keywords: Analgesic, anova, keji beling leaves, white male wistar rats.

\begin{abstract}
ABSTRAK
Rasa nyeri merupakan pengalaman sensorik dan emosional yang tidak menyenangkan akibat kerusakan jaringan baik aktual maupun potensial. Analgesik ialah suatu obat yang digunakan untuk menghilangkan rasa sakit tanpa menghilangkan kesadaran. Daun keji beling (Strobilanthes crispus L) mengandung senyawa glikosidik ester dari asam caffeic yang memiliki efek analgesik. Penelitian ini bertujuan untuk mengetahui ada tidaknya efek analgesik pada ekstrak etanol daun keji beling dengan dosis berbeda-beda yaitu dosis 0,0023g/200gBB, 0,0047g/200gBB, dan 0,0094g/200gBB pada hewan uji tikus putih jantan galur wistar. Penelitian ini menggunakan Rancangan penelitian eksperimental laboratorium dengan menggunakan hewan uji tikus putih jantan galur wistar. Pengujian efek analgesik dilakukan dengan metode rangsangan panas menggunakan waterbath suhu $53^{\circ} \mathrm{C}$. Respon tikus diamati berupa gerakan menjilat kaki belakang atau melompat dari sebelum pemberian bahan uji dan sesudah pemberian bahan uji berturut-turut pada menit ke 30, 60, 90 dan 120 . Dari hasil analisis data secara statistika dengan One Way Anova dan LSD menunjukkan bahwa ekstrak daun keji beling memiliki efek analgesik. Dimana antara ketiga dosis tersebut yang paling terbaik ialah dosis $0,0023 \mathrm{~g} / 200 \mathrm{gBB}$.
\end{abstract}

Kata kunci : Analgesik, Anova, Daun Keji Beling, tikus putih jantan galur wistar 


\section{PENDAHULUAN}

Definisi nyeri menurut The International Asosiation for the Study of Pain ialah suatu pengalaman sensorik dan emosional yang tidak menyenangkan yang disertai dengan kerusakan jaringan secara potensial dan aktual. Rasa nyeri merupakan mekanisme perlindungan dan pertahanan bagi tubuh. Selain itu nyeri berfungsi sebagai defensif yaitu memungkinkan untuk immobilisasi organ tubuh yang mengalami inflamasi atau patah, sehingga sensible yang dirasakan akan mereda dan bisa mempercepat penyembuhan, (Tudang et al., 2013). Ambang toleransi nyeri pada setiap orang berbeda - beda. Dimana ambang nyeri tersebut adalah tingkat (level) nyeri di rasakan pertama kali atau intensitas rangsangan yang terendah saat seseorang merasakan nyeri (Tjay dan Rahardja, 2002).

Analgesik adalah salah satu obat yang digunakan untuk mengurangi dan menghilangkan rasa sakit atau obat penghilang rasa nyeri tanpa menghilangkan kesadaran.

Pada umumnya, obat tradisional tidak menyebabkan efek samping serius dan aman untuk pemakaian pada manusia (Dalimarta, 2000). Berbagai jenis tumbuhan di Indonesia digunakan oleh masyarakat sebagai sumber bahan obat alam untuk pengobatan secara tradisonal. Salah satu ialah tanaman yang dapat dimanfaatkan sebagai bahan obat tradisional adalah tanaman keji beling (Strobilanthes crispus L) yang diketahui memiliki manfaat untuk berbagai pengobatan seperti batu ginjal, diabetes melitus, maag dan sebagai laksatif (mengatasi sembelit) (Gunawan,
2011).Daun keji beling (Strobilanthes crispus L) mengandung sejumlah besar senyawa aktif seperti mineral (pottasium, kalsium, sodium, kalium, besi dan fosfor), vitamin larut air (C, B1, dan B2), vitamin E, katekin, tannin, kumarin, flavonoid, dan steroid) (Setyaningsih, 2008).

\section{METODOLOGI PENELITIAN \\ Waktu dan Tempat Penelitian}

Penelitian dilakukan pada bulan Mei sampai Agustus 2019 di Laboratorium Lanjutan Farmasi Program Studi Farmasi Fakultas Matematika dan Ilmu Pengetahuan Alam Universitas Sam Ratulangi, Manado.

\begin{abstract}
Alat
Alat-alat gelas (pyrex), oven, blender (Philips), pengayak, wadah, pisau, timbangan analitik, timbangan tepung, sarung tangan, kandang pemeliharaan hewan, tempat air minum dan makanan hewan, sudip, kertas saring, aluminium foil, termometer, lumpang dan alu, sonikasi, pot salep, hot plate, waterbath, stopwatch, disposable syringe $1 \mathrm{ml}$, dan sonde oral.
\end{abstract}

\section{Bahan}

Dalam penelitian ini bahan yang digunakan yaitu : Daun keji beling, etanol 96\%, aquadest, CMC 1\%, Parasetamol, dan makanan hewan uji.

\section{Hewan Uji}

Objek yang digunakan dalam penelitian ini merupakan tikus putih jantan galur wistar (Rattus novergicus) yang berumur $2-3$ bulan dan berat badan 100200 gram dengan jumlah 15 ekor. 


\section{Rancangan Penelitian}

Penelitian ini menggunakan rancangan penelitian eksperimental laboratorium dengan menggunakan tikus putih jantan sebagai hewan percobaan. Perlakuan dibagi dalam 5 kelompok, dalam kelompok masing-masing terdiri dari 3 ekor tikus putih jantan yang sudah diadaptasikan terlebih dahulu terhadap lingkungan kurang lebih 10 hari.

Pembagian kelompok perlakuan sebagai berikut :

\section{$\mathrm{K}(-)$ : diberikan suspensi $\mathrm{CMC} 1 \%$} sebanyak $1 \mathrm{ml}$

$\mathrm{K}(+)$ : diberikan suspensi parasetamol dosis $12,6 \mathrm{mg} / \mathrm{tablet}$

KP1 : diberikan suspensi ekstrak etanol daun keji beling sebanyak 0,0023 g

KP2 : diberikan suspensi ekstrak etanol daun keji beling sebanyak $0,0047 \mathrm{~g}$

KP3 : diberikan suspensi ekstrak etanol daun keji beling $0,0094 \mathrm{~g}$

\section{Pembuatan Simplisia dan Proses Ekstraksi}

Daun Keji Beling (Strobilanthes crispus L) yang diambil dicuci bersih sebanyak 6,8 kg sampel daun keji beling. Kemudian daun keji beling dikeringkan dengan cara diangin anginkan, hingga daunnya mengering. Sampel yang sudah kering dihaluskan menggunakan blender lalu diayak dengan pengayak. Serbuk daun keji beling ditimbang sebanyak 400 gram dimasukkan kedalam wadah, kemudian ditambahkan pelarut etanol 96\% sebanyak $2000 \mathrm{ml}$ dengan perbandingan 1:5 sampai sampel terendam secara keseluruhan kemudian sampel ditutup, perendaman dilakukan selama 5 hari dan terlindung dari cahaya.
Selama perendaman dilakukan pengadukan setiap hari. Setelah 5 hari, dilakukan penyaringan menggunakan kertas saring menghasilkan filtrat dan debris. Selanjutnya dilakukan proses remaserasi dengan ekstrak etanol 96\% sebanyak $1200 \mathrm{ml}$ dengan perbandingan 1:3 selama 2 hari. Filtrat yang peroleh digabungkan dan dipekatkan menggunakan oven pada suhu $40^{\circ} \mathrm{C}$ sampai diperoleh ekstrak kental.

\section{Pembuatan Larutan CMC 1\%}

Sebanyak 1 gram CMC ditaburkan dalam beaker glass yang berisi $10 \mathrm{ml}$ aquades yang telah dipanaskan, aduk sampai mengembang kemudian dihaluskan sampai homogen. Selanjutnya dimasukkan ke dalam labu ukur dan ditambahkan aquades sampai volume $100 \mathrm{ml}$.

\section{Dosis Parasetamol}

Tiap tablet parasetamol mengandung $500 \mathrm{mg}$. Takaran konversi dosis parasetamol pada manusia dengan berat badan $70 \mathrm{~kg}$ dan pada tikus dengan berat badan $200 \mathrm{~g}$ adalah 0,018. Rata-rata orang indonesia beratnya $50 \mathrm{~kg}$, maka dosis untuk tikus adalah :

$=(70 / 50 \times 500 \mathrm{mg}) \times 0.018$

$=12,6 \mathrm{mg}$

\section{Dosis Ekstrak etanol daun keji beling}

Takaran konversi dosis untuk manusia dengan berat badan $70 \mathrm{~kg}$ pada tikus dengan berat badan 200 gram adalah 0.018 g. Rata-rata orang indonesia beratnya $50 \mathrm{~kg}$. Dosis pemakaian ekstrak daun keji beling (Strobilanthes crispus L) dosis yang akan digunakan masyarakat adalah 15 gram (dapat dilihat pada lampiran perhitungan ekstrak) maka Dosis pemakaian daun keji beling pada tikus putih adalah : 


$$
\begin{aligned}
& =(70 / 50 \times 0.19 \mathrm{~g}) \times 0,018 \\
& =0.266 \times 0.018 \\
& =0,0047 \mathrm{~g} / 200 \mathrm{~g} \text { BB tikus } \\
& \text { Dalam percobaan digunakan dosis }
\end{aligned}
$$
ekstrak daun keji beling yang bertingkat yang terbagi:

$\mathrm{KP} 1=0,5 \times 0.0047 \mathrm{~g}=0.0023 \mathrm{~g} / 200 \mathrm{gBB}$

$\mathrm{KP} 2=1 \times 0.0047 \mathrm{~g}=0.0047 \mathrm{~g} / 200 \mathrm{gBB}$

KP $3=2 \times 0.0047 \mathrm{~g}=0.0094 \mathrm{~g} / 200 \mathrm{gBB}$

\section{Induksi Nyeri Cara Termik dengan Tipe Nyeri Visceral}

Uji efek analgesik menggunakan metode induksi dengan cara termik yaitu dengan cara memasukkan tikus ke dalam beaker glass yang telah dipanaskan dalam waterbath pada suhu $53^{\circ} \mathrm{C}$ sebagai stimulus nyeri dan tikus akan memberikan respon dalam bentuk menjilat kaki dan atau melompat. Selang waktu antara pemberian stimulus nyeri dan terjadi respon disebut waktu reaksi. Waktu reaksi ini dapat diperpanjang oleh obat-obat analgesik. Perpanjang waktu reaksi ini selanjutnya dapat dijadikan sebagai ukuran mengevaluasi aktivitas analgesik (Turner, 1965).

\section{Pengujian Efektivitas Analgesik}

Langka-langka pengujian efek analgesik pada hewan uji adalah sebagai berikut yaitu:

a. Beaker glass diletakkan diatas waterbath yang berisi air dan kemudian waterbath dipanaskan hingga $53^{\circ} \mathrm{C}$. Setelah suhu mencapai $53^{\circ} \mathrm{C}$ tikus dimasukkan kedalam beaker glass tersebut.

b. Setelah tikus ada di dalam beaker glass maka responnya diamati, yaitu berupa gerakan menjilat kaki dan atau melompat, pengamatan dilakukan selama 1 menit.

c. Kelompok kontrol negatif diberikan CMC 1\%, kelompok kontrol positif diberikan parasetamol dan kelompok perlakuan diberikan ekstrak etanol daun keji beling. Tikus lalu diistirahatkan untuk diamati kembali pada menit ke-30

d. Pengamatan dilakukan hingga menit ke-120, dengan interval waktu 30menit untuk setiap pengamatan. Pengamatan dilakukan sebanyak 5 kali yaitu :

1. Sebelum pemberian bahan uji

2. Menit ke-30

3. Menit ke-60

4. Menit ke-90

5. Menit ke-120

\section{Analisis Data}

Data hasil pengamatan dikumpulkan dan disajikan dalam bentuk tabel, grafik dan analisis statistik menggunakab uji One-Way Anova (Analysis Of Variance) untuk mengetahui pengaruh ekstrak etanol daun keji beling terhadap tikus putih galur wistar (Rattus norvegicus) dan menggunakan Least Significant Difference (LSD) untuk menguji signifikansi dari perbedaan ratarata antar kelompok perlakuan

\section{HASIL DAN PEMBAHASAN \\ Hasil}

Data hasil penelitian berikut ialah data data yang diperoleh ke 5 kelompok perlakuan hewan uji masing-masing kelompok terdiri dari 3 ekor hewan uji tikus. Hasil rata-rata penurunan respon tikus (jilatan \& lompatan) terhadap kontrol negatif, kontrol positif dan ekstrak etanol 
daun keji beling dapat dilihat sebagai berikut :

Tabel 1. Hasil rata-rata penurunan respon tikus sebelum dan sesudah pemberian bahan uji

\begin{tabular}{|c|c|c|c|c|c|}
\hline \multirow{2}{*}{$\begin{array}{l}\text { Kelompok } \\
\text { perlakuan }\end{array}$} & \multirow{2}{*}{$\begin{array}{c}\text { Sebelum } \\
\text { Pemberian } \\
\text { Bahan Uji }\end{array}$} & \multicolumn{4}{|c|}{ Setelah Pemberian Bahan Uji } \\
\hline & & $\begin{array}{l}\text { Menit } \\
\text { ke-30 }\end{array}$ & $\begin{array}{l}\text { Menit } \\
\text { ke-60 }\end{array}$ & $\begin{array}{l}\text { Menit } \\
\text { ke-90 }\end{array}$ & $\begin{array}{c}\text { Menit } \\
\text { ke-120 }\end{array}$ \\
\hline $\begin{array}{l}\text { Kontrol } \\
\text { Negatif }\end{array}$ & 13,3 & 13,6 & 16,6 & 10,6 & 18 \\
\hline $\begin{array}{l}\text { kontrol } \\
\text { Positif }\end{array}$ & 12,3 & 15,6 & 3 & 2,6 & 1 \\
\hline KP1 & 13 & 4 & 3,3 & 2,6 & 1,6 \\
\hline KP2 & 15,6 & 1,3 & 1,6 & 1,3 & 0,6 \\
\hline KP3 & 14 & 1,3 & 0,3 & 1 & 0,3 \\
\hline
\end{tabular}

Keterangan :

$\mathrm{K}(-)$ : Kelompok kontrol negatif

$\mathrm{K}(+)$ : Kelompok kontrol positif

KP1 : Kelompok perlakuan ekstrak daun keji beling dosis 0,0023 g

KP2 : Kelompok perlakuan ekstrak daun keji beling dosis 0,0047 g

KP3 : Kelompok perlakuan ekstrak daun keji beling dosis 0,0094 g

\section{PEMBAHASAN}

Penelitian ini dilakukan untuk mengetahui ada tidaknya efek analgesik dari ekstrak etanol daun keji beling ini, terhadap hewan uji yang menngunakan metode rangsangan panas. Rangsangan nyeri yang diberikan pada penelitian ini adalah metode induksi cara termik, dengan cara memasukkan tikus ke dalam beaker gelas yang sudah diletakkan di atas waterbath pada suhu $53^{\circ} \mathrm{C}$ sebagai stimulus nyeri. Pada penelitian ini respon tikus yang di nilai berupa gerakan menjilat kaki belakang atau melompat sebagai

ketentuan bahwa tikus mulai merasakan nyeri pada waktu menjilat kaki atau melompat. Induksi nyeri cara termik dalam penelitian ini mengunakan suhu $53^{\circ} \mathrm{C}$ karena suhu kritis rata-rata nyeri sebesar $45^{\circ} \mathrm{C}$ saat seseorang mulai merasakan sakit dan reseptor panas mempunyai respon terhadap suhu 30 $45^{\circ} \mathrm{C}$. Kemudian suhu diatas $45^{\circ} \mathrm{C}$ dimana, mulai terjadi kerusakkan jaringan akibat panas dan sensasinya berubah menjadi nyeri.(Guyton,2011). 
Hasil perhitungan rata-rata respon tikus sebelum dan setelah perlakuan selawng waktu 30 menit ini, menjelaskan bahwa penurunan respon tikus paling kecil yaitu terlihat pada kelompok perlakuan kontrol negatif CMC, sedangkan kelompok perlakuan kontrol positif parasetamol dan ekstrak dengan dosis $0,0023 \mathrm{~g} / 200 \mathrm{gBB}, \quad 0,0047 \mathrm{~g} / 200 \mathrm{gBB}$, dan $0,0094 \mathrm{~g} / 200 \mathrm{gBB}$ respon tikus hampir sama. Hal ini menunjukan bahwa suspensi paracetamol dan ekstrak mampu menurunkan respon tikus pada efek analgesik.

Pada kelompok kontrol negatif yang diberikan suspensi CMC $1 \%$ sebelum dan setelah pemberian bahan uji hingga menit ke-120 respon tikus tidak mengalami penurunan dari menit ke-30 hingga menit ke-120 respon tikus semakin tinggi. Hal ini menunjukkan bahwa kontrol negatif CMC tidak terkandung zat aktif yang dapat mengurangi respon nyeri. Pada kelompok perlakuan kontrol positif digunakan parasetamol karena parasetamol ini sudah terbukti memiliki efek analgesik yang secara luas telah digunakan masyarakat. Pemberian suspensi parasetamol dengan dosis $12,9 \mathrm{mg}$ terjadi penurunan respon rata-rata hewan uji terhadap rangsanan nyeri. Dilihat dari sebelum pemberian hewan uji hingga menit ke 120, efek analgesik kontrol positif parasetamol pada penelitian ini terdapat pada menit ke 30 dimana terjadi penurunan respon tikus hingga menit ke120. Dapat dikatakan bahwa suspensi parasetamol memiliki efek analgesik.

Pada kelompok perlakuan ekstrak daun keji beling yang diberikan dosis yang berbeda-beda. Dimana ekstrak daun keji beling mempunyai efek analgesik. Hal ini dapat dilihat penurunan rata rata respon nyeri pada hewan uji dari sebelum pemberian bahan uji dan setelah pemberian hingga menit ke-120. Pada kelompok perlakuan satu ekstrak dosis $0,0023 \mathrm{~g} / 200 \mathrm{gBB}$, hasil menunjukkan respon tikus terhadap nyeri pada menit ke30 dan terus terjadi penurunan hingga menit ke-120 efek analgesiknya mulai hilang. Ini menunjukkan bahwa ekstrak daun keji beling dosis 0,0023 g memiliki efek analgesik.

Kolompok perlakuan dua ekstrak daun keji beling dosis $0,0047 \mathrm{~g} / 200 \mathrm{gBB}$, hasil menunjukkan adanya respon nyeri dilihat dari menit ke-30 dan ke-60 efek analgesik tetap stabil. Menit ke-90 mulai terjadi penurunan respon hewan uji hingga menit ke-120 respon hewan uji hilang. Ini menunjukkan bahwa ekstrak daun keji beling dosis 0,0047 $\mathrm{g}$ memiliki efek analgesik

Pada kelompok perlakuan tiga ekstrak daun keji beling dosis 0,0094g/200gBB, hasil menunjukkan adanya respon nyeri dilihat pada menit ke30 terjadi penurunan respon tikus hingga menit ke-60. Menit ke 90 respon rata-rata terhadap nyeri naik, dan menit ke-120 respon tikus pada efek analgesik hilang. Hal ini menunjukkan bahwa ekstrak daun keji beling dosis 0,0094 g memiliki efek analgesik.

Pada penelitian ini kelompok perlakuan satu ekstrak daun keji beling dosis 0,0023 g memiliki efek analgesik yang paling baik dalam kelompok perlakuan karena dari sebelum pemberian bahan uji hingga menit ke-120 respon geliat tikus mengalami penurunan secara bertahap dapat dilihat pada tabel 1.walaupun hanya dosis yang rendah tetapi ekstrak daun keji beling memberikan efek analgesik yang baik dibandingkan dengan 
dosis $\quad 0,0047 \quad \mathrm{~g} / 200 \mathrm{gBB} \quad$ dan $\quad 0,0094$ $\mathrm{g} / 200 \mathrm{gBB}$.

Pada hasil penurunan respon tikus kelompok perlakuan ekstrak daun keji beling. Dimana kelompok perlakuan satu, hasil penurunan respon tikus terhadap nyeri sangat baik dibandingan kelompok perlakuan dua dan tiga respon tikus terhadap nyeri tidak stabil kemungkinan dikarenakan pada saat pengujian respon tikus tersebut seperti melompat bukan karena nyeri, tetapi ada gangguan dari dalam ruangan selama pengujian. Dalam memperoleh data yang lebih spesifik pada efek analgesik ekstrak etanol daun keji beling, maka dilakukan uji statistika One Way Anova dan kemudian dilanjutkan dengan uji LSD (Least significant different).

Hasil pengujian dengan One Way ANOVA, dengan lima kelopok perlakuan yaitu kontrol negatif $\mathrm{CMC} 1 \%$, kontrol positif parasetamol dosis $12,6 \mathrm{mg}$ dan 3 kelompok perlakuan ekstrak etanol (dosis $0,0023 \mathrm{~g}, 0,0047 \mathrm{~g}$ dan $0,0094 \mathrm{~g}$ ) dapat dilihat pada tabel 2. Dimana data yang diperoleh nilai signifikan $=0,033$ $(\operatorname{sig}<0,05)$ yang berarti ada perbedaan yang bermakna antara kelima kelompok perlakuan. Dapat disimpulkan bahwa ekstrak etanol daun keji beling memiliki efek analgesik yang dapat mengurangi respon nyeri pada hewan uji, karena hasil uji One Way Anova mengatakan H1 diterima dan ditolak $\mathrm{H} 0$.

Pada pengujian Test of homogenity of variance untuk mengetahui kelompok perlakuan mana yang memiliki perbedaan yang signifikan, artinya Uji homogenitas tersebut digunakan untuk mengetahui apakah lima kelompok perlakuan tersebut berasal dari populasi yang memiliki varians sama. Dimana hasil pengujian antara lima kelompok (kontrol negatif CMC 1\%, kontrol positif parasetamol dosis 12,6 mg dan 3 kelompok perlakuan ekstrak dosis $0,0023 \mathrm{~g}, 0,0047 \mathrm{~g}$ dan $0,0094 \mathrm{~g}$ ), dapat dilihat pada tabel 3. Hasil uji yang diperoleh nilai signifikan $=0,522$ (sig $>0,05)$ yang menyatakan H0 diterima dan ditolak H1. Yang berarti tidak ada perbedaan yang bermakna antara kelima kelompok tersebut.

Pada pengujian LSD (Least significant different) untuk mengetahui adanya perbedaan nilai rata-rata penurunan respon tikus dari sebelum perlakuan dan sesudah perlakuan pada menit ke-30, 60, 90, 120 antara ke-lima kelompok perlakuan yang berbeda-beda (kontrol negatif CMC 1\%, kontrol positif parasetamol dosis 12,6 $\mathrm{mg}$ dan 3 kelompok perlakuan ekstrak dosis 0,0023 g, 0,0047 g dan 0,0094 g), dapat dilihat pada lampiran 14. Dimana hasil pengujian LSD menunjukkan bahwa kontrol negatif ada perbedaan antara kontrol positif dan kelompok perlakuan ekstrak. Sedangkan kelompok perlakuan ekstrak etanol daun keji beling tidak mengalami perbedaan dengan kontrol positif. Ini menunjukkan bahwa pemberian ekstrak etanol daun keji beling memiliki efek untuk mengurangi respon hewan uji tikus.

Dilihat dari ketiga kelompok perlakuan ekstrak etanol daun keji beling dosis yang berbeda-beda. Dimana penelitian ini membuktikan bahwa secara farmakologi ekstrak tersebut memiliki efek analgesik. Ekstrak daun keji beling memiliki efek analgesik karena adanya kandungan senyawa glikosidik ester dari asam caffeic (Soediro et al.,1983). Daun keji beling tersebut memiliki kandungan flavonoid. Dimana menurut Christiana et $a l$, (2012), senyawa flavonoid berperan 
sebagai analgesik dengan cara menghambat kerja enzim siklooksigenase dengan mengurangi produksi prostaglandin oleh asam arakidonat sehingga dapat mengurangi rasa nyeri. Selain itu senyawa flavonoid juga menghambat degradulasi neutrofil sehingga akan menghambat pengeluaran sitokin, radikal bebas, serta enzim yang berperan pada peradangan.

\section{KESIMPULAN}

Berdasarkan hasil penelitian yang dilakukan, dapat disimpulkan bahwa pemberian ekstrak etanol daun keji beling (Strobilanthes criptus L) dosis 0,0023g/200gBB, 0,0047g/200gBB dan $0,0094 \mathrm{~g} / 200 \mathrm{gBB}$ pada tikus putih jantan (Rattus norvegicus) memiliki efek analgesik tipe visceral. Dimana antara ketiga dosis tersebut yang paling terbaik ialah dosis $0,0023 \mathrm{~g} / 200 \mathrm{gBB}$

\section{SARAN}

Disarankan kepada penelitian selanjutnya agar dapat dilakukan penelitian lebih lanjut mengenai penentuan dosis minimum, maksimum dan dosis toksik, agar ditentukan dosis yang optimal dari ekstrak etanol daun keji beling (Strobilanthes criptus L).

\section{DAFTAR PUSTAKA}

Christiana, I., Evacuasiany, E., Hidayat, M. 2012. The Analgenic Effect Of Kayu Rapat Bark Infusion (Parameria laevigata (Juss) Moldenke) On Male Mice Treated With Termal Inducation. Jurnal Medika Planta. 02 (01).
Dalimartha, S. 2000. Atlas Tumbuhan Obat Indonesia Jilid 2. Trubus Agriwidya, Jakarta.

Gunawan, I. 2011. Efek Kejibeling (Sericocalyx Crispus L) Terhadap Penurunan Tekanan Darah Pria Dewasa [Skripsi]. Fakultas Kedokteran Universitas Kristen Maranatha, Bandung.

Guyton dan Hall. 2011. Buku Ajar Fisiologi Kedokteran. Elsevier, Singapore

Soediro, L., Pellecuer, J., Andary, C., and Privat, G. (1983). Strobilanthes crispus (L.) Bl. I: Pemeriksaan senyawa turunan asam kafeat verbaskosid. Acta Pharm. Indones., VIII(I), 1-10.

Setyaningsih, D. 2008. Uji Efek Infusa Daun Keji Beling Terhadap Penurunan Kadar Glukosa Darah Kelinci Jantan. Universitas Muhammadiah, Surakarta.

Turner, R. A. 1965. Screening Methods In Pharmacology. Academia Press, New York.

Tjay, T., H., dan Rahardja, K. 2002. Obat - obat Penting, Khasiat, Penggunaan dan Efek Sampingnya. Edisi V. PT. Elex Media Komputindo Kelompok Gramedia, Jakarta.

Tudang, A., Wuisan, J., dan Najoan, A.J. 2013. Uji Efek Analgesik Ekstrak Daun Picisan (Polypodiumnummulariifolium Mett.) Pada Mencit Swiss (Mus musculus). Jurnal e-Biomedik (eBM). Vol 01:02. 